\title{
The extracellular acid protease gene of Yarrowia lipolytica: sequence and pH-regulated transcription
}

\author{
Thomas W. Young, Albert Wadeson, David J. Glover, Roger V. Quincey, \\ Michael J. Butlin and Elizabeth A. Kamei†
}

Author for correspondence: Thomas W. Young. Tel: + 441214145437. Fax: + 441214143982.
e-mail: t.w.young@ bham.ac.uk

School of Biochemistry, University of Birmingham, Edgbaston, Birmingham, B15 2TT, UK

\begin{abstract}
The gene encoding an acid extracellular protease (AXP) from Yarrowia lipolytica (Candida olea) 148 was cloned and the complete nucleotide sequence was determined. The amino acid sequence deduced from the nucleotide sequence reveals that the mature AXP consists of 353 amino acids with an $M_{r}$ of 37427 . The gene also encodes a putative 17 amino acid hydrophobic prepeptide and a 27 amino acid propeptide containing no potential $\mathbf{N}$ glycosylation sites. The mature extracellular enzyme is produced by cleavage between Phe and Ala. AXP is a member of the aspartyl family of proteases. AXP shows homology to proteases of several fungal genera and to human progastricin. The coding sequence is preceded by a potential regulatory region of 1982 bp. Transcription of both AXP and alkaline extracellular protease genes of $Y$. lipolytica 148 is regulated by the $\mathrm{pH}$ of culture.
\end{abstract}

Keywords: yeast, Yarrowia lipolytica, extracellular protease, aspartyl protease, $\mathrm{pH}$ regulation

\section{INTRODUCTION}

Yarrowia lipolytica (syn. Candida olea, Candida lipolytica, Saccharomycopsis lipolytica) is a heterothallic, ascosporogenous yeast which exhibits growth in budding, pseudomycelial and true mycelial forms. It has been used commercially for the production of citric acid and singlecell protein and may also be used to produce erythritol, mannitol and isopropylmalic acid. Although less welldeveloped than in Saccharomyces cerevisiae, the genetics of Yarrowia have been analysed and a genetic map is available (Heslot, 1990). Y. lipolytica is a natural secretor of proteins and offers advantages over Saccharomyces cerevisiae as a eukaryotic host for secretion of heterologous proteins such as bovine prochymosin (reviewed by Heslot, 1990, and Ogrydziak, 1993).

In common with many yeasts (reviewed by Ogrydziak, 1993), strains of $Y$. lipolytica secrete proteolytic enzymes showing optimal activity at acidic, neutral or alkaline $\mathrm{pH}$

\footnotetext{
†Present address: Faculty of Engineering, Gunma University, 5-1 Tenjin Cho 1 Chome Kiryu Shi, Gunma, Japan 376.

Abbreviations: AEP, alkaline extracellular protease; AXP, acid extracellular protease; DEPC, diethyl pyrocarbonate.

The GenBank accession number for the sequence reported in this paper is X97068.
}

values. Strain 148 secretes one acid and one alkaline protease (Nelson \& Young, 1987), and the former enzyme has been considered for use in the brewing industry as a chill-proofing agent for beer (Nelson \& Young, 1986). As in other strains (Ogrydziak, 1993), production of both proteolytic enzymes by strain 148 is subject to repression by nitrogen (ammonium ions, amino acids) and sulphur and may be induced by the presence of protein (Nelson, 1986).

The gene $(x p r 2)$ for the alkaline extracellular protease (AEP) from $Y$. lipolytica has been sequenced (Davidow et al., 1987a) and a complex potential upstream regulatory region identified. Analysis of the regulatory region (Blanchin-Roland et al., 1994) showed that a TATA box and two major upstream activation sequences were essential for promoter activity under conditions of repression or full induction. The sequences identified as important showed similarities to GCN4, TUF/R AP1 and CAR 1 of Saccharomyces cerevisiae. The data of Blanchin-Roland et al. (1994) strongly suggested that the upstream activation sequence regions were targets for transcriptional factors required for assisting specific regulatory proteins.

Secretion of the AEP of Y. lipolytica CX161-1B most probably proceeds from a $55 \mathrm{kDa}$ precursor produced after cleavage of a 15 amino acid signal peptide. This 
precursor is then processed by a diaminopeptidase to generate a $52 \mathrm{kDa}$ proprotein which is subsequently cleaved to give the mature $32 \mathrm{kDa}$ secreted protein. This final step probably utilizes a KEX2-like protease (Ogrydziak, 1993). Sequence comparison between the prepro regions of Y. lipolytica AEP (Matoba et al., 1988; Davidow et al., 1987a) and the acid proteases of Saccharomycopsis fibuligera (Hirata et al., 1988), Candida albicans strains 10231 (Hube et al., 1991) and 10261 and Candida tropicalis (Togni et al., 1991) has led to the suggestion that there may be a common motif in processing yeast extracellular proteases (Ogrydziak, 1993). This motif is proposed to comprise a Lys-Arg (or Arg-Arg) pair of basic amino acids immediately preceding the $\mathrm{N}$-terminus of the mature enzymes and two further potential common processing sites in the pro region. These sites, a Lys-Arg cleavage locus and a consensus glycosylation sequence, are in the same locations relative to the pro regions of the acid proteases. Whether or not these sites are used is unknown. In $Y$. lipolytica AEP, sites in the same order but with different spacings are seen. AEP is glycosylated in the pro region and it is possible that the secreted enzyme contains $O$ linked carbohydrate. Although the sequence of the mature protein contains two consensus $N$-linked glycosylation sites they are not used. The acid proteases of other strains are variously reported as being glycosylated in the secreted form.

Several authors have shown that environmental $\mathrm{pH}$ influences the activities of Yarrowia extracellular proteases (Ogrydziak, 1993). In general, high pH favours alkaline enzyme activity and low $\mathrm{pH}$ favours acid enzyme activity (Ogrydziak, 1993). Previous work in this laboratory showed that the accumulation of protease activity in the medium by Candida olea 148 (syn. $Y$. lipolytica) was influenced by environmental pH (Nelson \& Young, 1987). The influence of environmental $\mathrm{pH}$ on enzyme synthesis and secretion is more readily measured in this strain because interference from both neutral proteases and a multiplicity of other proteases is absent. When strain 148 was grown on medium with protein as the sole source of nitrogen and sulphur, an acid (carboxyl) protease activity was produced in culture over the range $\mathrm{pH} \mathrm{2-6}$ and an alkaline (serine) protease at $\mathrm{pH}$ 6-9 (Nelson \& Young, 1987). However, none of the published work with this or other strains has established the biochemical basis for the $\mathrm{pH}$ effect. This could be facile, at the level of the known $\mathrm{pH}$-dependence of enzyme activity, or involve other processes such as the secretory pathway, gene transcription or translation. The mechanism whereby environmental $\mathrm{pH}$ influences extracellular protease activity is important since if, for example, regulation of gene expression is involved this clearly has significance for mechanisms of cell signalling as well as providing a process for the $\mathrm{pH}$-directed expression of secreted heterologous proteins.

In Aspergillus nidulans, PacC (a zinc-finger transcription factor) has been shown to mediate $\mathrm{pH}$ regulation of both acid- and alkaline-expressed genes by environmental $\mathrm{pH}$ (Tilburn et al., 1995). This transcription factor binds to a core hexanucleotide sequence in the promoter region of the alkaline-regulated isopenicillin $N$-synthetase structural gene $(i p n A)$. The pac $C$ gene product is activated under conditions of alkaline environmental $\mathrm{pH}$ by proteolysis (Orejas et al., 1995). In $A$. niger, the $p e p A$ and $p e p B$ genes encoding acid extracellular proteases have been shown to be regulated at the level of gene transcription by the $\mathrm{pH}$ of the environment (Jarai \& Buxton, 1994). An 18 bp sequence showing $83 \%$ similarity lies upstream of the transcription start of both these genes and may represent a locus for $\mathrm{pH}$ regulation of transcription. In the yeast $C$. albicans, environmental $\mathrm{pH}$ has been shown to influence the transcription of the messenger for a secreted aspartyl protease (SAP2). It is proposed that this effect, however, is dependent also on either the phase of growth or the presence of an inducing agent in the medium (Hube et al., 1994).

In this paper we report the cloning and sequencing of the gene and potential regulatory region for the secreted acid protease of the yeast $Y$. lipolytica strain 148, and show that the transcription of both the genes for acid and alkaline protease is regulated by the $\mathrm{pH}$ of the culture medium.

\section{METHODS}

Strains. Y. lipolytica 148 (syn. Saccharomycopsis lipolytica, C. lipolytica, C. olea; see Results) was maintained as described by Nelson \& Young (1987). Genomic libraries were made in Escherichia coli DH5 (Hanahan, 1985) using the plasmid vector YCp50 (Johnson \& Davis, 1984).

Maintenance and cultivation of micro-organisms. E. coli $\mathrm{DH} 5$ was maintained on LB broth or agar. Ampicillin $\left(50 \mu \mathrm{g} \mathrm{ml}^{-1}\right)$ was included in the medium for maintenance of plasmids. Medium for maintenance of yeast was YM broth or agar (Difco).

For culture of yeasts to produce extracellular enzymes, a 161 fermenter (Biolafitte) was used. Automatic monitoring and control were used to maintain an agitation rate of 300 r.p.m, temperature of $30^{\circ} \mathrm{C}, \mathrm{pH}$ of 4.5 (for acid protease production) or 6.5 (for alkaline protease production). The culture was grown with continuous aeration and the level of dissolved oxygen did not fall below $70 \%$ of saturation. The medium was $0.2 \%$ BSA, $1 \%(\mathrm{w} / \mathrm{v})$ glucose, $0.143 \%$ yeast nitrogen base (YNB) without amino acids and ammonium sulphate (Gibco). Glucose solution was sterilized in situ in the fermenter. A concentrated aqueous solution (2 1) of YNB and BSA was sterilized by filtration through a $0.2 \mu \mathrm{m}$ Sartobran-PH Capsule (Sartorius) and pumped directly into the sterile glucose solution.

Small batch cultures were used to analyse the effect of extracellular $\mathrm{pH}$ on the synthesis of enzyme transcripts. The medium contained $2 \%(\mathrm{w} / \mathrm{v})$ BSA, $1 \%(\mathrm{w} / \mathrm{v})$ D-glucose, $0.143 \%$ YNB. Acid $\mathrm{pH}$ was maintained using 0.5 M MES buffer, $\mathrm{pH} 5 \cdot 5$, and alkaline conditions were maintained using $0.5 \mathrm{M}$ MOPS buffer, $\mathrm{pH} 7 \cdot 5$. One hundred millilitres of medium in $250 \mathrm{ml}$ baffled flasks (Sigma) were used. $\mathrm{D}$-Glucose $(2 \mathrm{ml}$ ) was sterilized by autoclaving $\left(110^{\circ} \mathrm{C}, 30 \mathrm{~min}\right)$ and added aseptically to $38 \mathrm{ml}$ sterile distilled water. BSA $(50 \mathrm{ml}$ of $4 \%)$ in $1 \mathrm{M}$ buffer at the appropriate $\mathrm{pH}$ and $10 \mathrm{ml} 1.43 \%(\mathrm{w} / \mathrm{v}) \mathrm{YNB}$ were sterilized by filtration through a $0 \cdot 2 \mu \mathrm{m}$ membrane filter (Minisart, Sartorius) and transferred aseptically to the sterilized glucose solution. Flasks were inoculated with a $10 \mathrm{ml}$ preculture $\left(48 \mathrm{~h}, 28^{\circ} \mathrm{C}\right.$, unshaken) and incubated in a gyratory shaker $(200$ r.p.m.) at $28^{\circ} \mathrm{C}$. Cultures were harvested at an $A_{600}$ value of $0.8-1.5$ after $16 \mathrm{~h}$ incubation. 
Yeast classification. A computer-assisted, yeast identification system (COMPASS) formerly offered by the National Collection of Yeast Cultures, Norwich, UK, was used to classify C. olea 148. The system comprises a probabilistic matrix prepared principally from data by Kreger-van Rij (1984). Morphological and physiological tests were conducted as described in the COMPASS manual.

Purification of extracellular proteases. The AXP of strain 148 was purified following culture at $\mathrm{pH} 4.5$ with $\mathrm{BSA}$ as the nitrogen source (Nelson \& Young, 1987). The methods used were as described by Nelson \& Young (1987) with the addition of two further chromatographic steps using an FPLC system (Pharmacia LKB). The first was elution from a Pharmacia Mono $\mathrm{Q}$ ion-exchange column (HR5/5) at a flow rate of $1 \mathrm{ml} \mathrm{min}^{-1}$. Sample was applied to the column in $0.01 \mathrm{M}$ sodium citrate $\mathrm{pH}$ 6.0 and eluted with $4 \mathrm{ml}$ of the same buffer and then with a $20 \mathrm{ml}$ linear gradient to $35 \%(\mathrm{v} / \mathrm{v})$ of $0.01 \mathrm{M}$ sodium citrate, $1 \mathrm{M}$ $\mathrm{NaCl} \mathrm{pH} 6.0$. The active material was chromatographed on a column $(10 \times 1 \mathrm{~cm})$ of Sephadex G25 to remove low- $M_{\mathrm{r}}$ components and then freeze-dried.

A single AEP was also isolated and purified from cultures grown at $\mathrm{pH}$ 6.5. The purification steps described by Ogrydziak $\&$ Scharf (1982) were used with the additional steps of FPLC on Mono Q and Sephadex G25. The Mono Q column was eluted at a flow rate of $2 \mathrm{ml} \mathrm{min}^{-1}$ with $5 \mathrm{ml}$ buffer A $(0.01 \mathrm{M}$ Tris $/ \mathrm{HCl}$, $\mathrm{pH} 8.4)$, followed by $15 \mathrm{ml} 7 \%(\mathrm{v} / \mathrm{v})$ buffer $\mathrm{B}(0.01 \mathrm{M}$ Tris/ $\mathrm{HCl}, 1 \mathrm{M} \mathrm{NaCl}, \mathrm{pH} 8.4)$ and a $10 \mathrm{ml}$ linear gradient from 7 to $15 \%$ of buffer $\mathrm{B}$.

Protein sequencing. This was conducted by the Amino Acid Sequencing Service of the BBSRC at the Department of Biochemistry, University of Leeds, Leeds, UK.

Synthesis of oligonucleotides. A mixed oligonucleotide (see Results) to a part of the N-terminal sequence (Fig. 1) of the secreted acid protease was synthesized by Alta Bioscience (an interfaculty service of the University of Birmingham). For probing the $Y$. lipolytica genomic library, $0 \cdot 1 \mu \mathrm{mol}$ mixed oligonucleotide was purified by butan-1-ol extraction and electroelution from a polyacrylamide sequencing gel (Sambrook et al., 1989). The oligonucleotide was labelled using polynucleotide kinase (BRL) and $\left[\gamma_{-}{ }^{32} \mathrm{P}\right]$ ATP $\left(300 \mathrm{Ci} \mathrm{mmol}{ }^{-1} / 11 \cdot 1\right.$ $\mathrm{TBq} \mathrm{mmol}^{-1}$; Amersham). The labelled nucleic acid was purified by electroelution from the radioactive band excised from a polyacrylamide gel; $1 \mathrm{ng}$ oligonucleotide emitted $10^{7}-10^{8}$ c.p.m.

Construction of genomic libraries of $Y$. lipolytica. Genomic DNA was isolated and purified using methods based on those published by Beggs (1978) and Riggsby et al. (1982). A partial $B a m \mathrm{HI}$ digest of genomic DNA was cloned into the unique Bam HI site of YCp50. A library of 46600 clones was made in $E$. coli DH5; 32600 clones of this library were probed by colony hybridization (Sambrook et al., 1989) with the labelled mixed oligonucleotide. A second library of a complete digest of Yarrowia genomic DNA with BglII was also made in YCp50.

DNA sequencing. Restriction fragments of DNA of positive clones isolated from the first library were subcloned into pUC9. These subclones were sequenced by the dideoxy method (Sambrook et al., 1989) using the M13 cloning system (Life Technologies; Messing, 1983) and universal primers. DNA from the second library was also sequenced by the dideoxy method using M13. In this case, however, oligonucleotide primers made to both the coding and the non-coding strands were used in the sequencing reactions. All sequence information reported has been obtained from the independent analysis of both strands.

Computer analysis of DNA sequences. Most analysis was conducted using versions 7 and 8 of the University of Wisconsin Genetics Computer Group (UWGCG) software on a VAX computer at the University of Birmingham. The same software and current databases were also used at Seqnet, Daresbury, UK, via the Joint Academic Network.

Isolation of total RNA. The methods used were based on those described by Quincey \& Arnold (1984) modified from those reported by Berger (1987a, b) and Kohrer \& Domdey (1991). All glassware and spatulas were baked overnight at $160^{\circ} \mathrm{C}$ prior to use. Solutions were treated with $0 \cdot 1 \%$ diethyl pyrocarbonate (DEPC) overnight and then autoclaved for $15 \mathrm{~min}$. Solutions of heat-labile materials were made up in DEPC-treated water and all chemicals were handled with baked spatulas.

Cultures were grown in shake flasks and $20 \mathrm{ml}$ culture (or a volume equivalent to $0.5 \mathrm{~g}$ centrifuged weight of cells) were poured through crushed ice into a sterile, polypropylene $50 \mathrm{ml}$ centrifuge tube. The cells were harvested by centrifugation at $4{ }^{\circ} \mathrm{C}$. The pellet was washed by resuspension in $20 \mathrm{ml}$ cold DEPC-treated water and collected as above. To the pellet, $2 \mathrm{~g}$ baked, acid-washed, $0.45 \mathrm{~mm}$ glass beads (Sigma) and $2 \mathrm{ml} \mathrm{ACE}$ I (sterile-filtered $50 \mathrm{mM}$ sodium acetate, $\mathrm{pH} 5 \cdot 2,10 \mathrm{mM}$ EDTA $\mathrm{pH} 8.0, \quad 0.2 \%$ heparin containing $10 \mathrm{mM}$ ribonucleoside vanadyl complexes; Sigma) were added. The whole was mixed vigorously on a vortex mixer for $8 \times 30 \mathrm{~s}$ periods with intermittent 30 s periods of cooling on ice. Two millilitres ACE II ( $50 \mathrm{mM}$ sodium acetate, $\mathrm{pH} 5 \cdot 2,10 \mathrm{mM}$ EDTA pH 8.0, 5\% SDS, $0 \cdot 1 \% 2$-mercaptoethanol, $10 \mathrm{mM}$ ribonucleoside vanadyl complexes) and $4 \mathrm{ml}$ phenol equilibrated to $\mathrm{pH} 4.5$ (Sigma) were added. The whole was mixed vigorously on a vortex mixer for $4 \times 30 \mathrm{~s}$ periods with intermittent $30 \mathrm{~s}$ periods of cooling on ice. The phases were separated by centrifugation, the organic phase was removed and the aqueous and inter-phases were reextracted with an equal volume of phenol/chloroform by vigorous mixing and cooling as before. The combined aqueous phases were re-extracted with phenol/chloroform. This process was repeated until no white interphase remained and then one further phenol/chloroform extraction was done followed by a final chloroform extraction. Finally, the aqueous layer was transferred to a fresh tube and the nucleic acid was precipitated by adding $0 \cdot 1$ vol. $3 \mathrm{M}$ sodium acetate, $\mathrm{pH} 5 \cdot 2$, and 2.5 vols cold absolute ethanol, mixing and leaving overnight at $-20^{\circ} \mathrm{C}$.

Fractionation of RNA through gels containing formaldehyde. The steps outlined above for the elimination of ribonuclease activity from materials and equipment were observed. In addition electrophoresis tanks, gel trays and combs were treated with DEPC overnight and rinsed with DEPC-treated water prior to use.

A volume of resuspended, ethanol-precipitated RNA (containing about $10 \mu \mathrm{g}$ nucleic acid) was centrifuged at $4{ }^{\circ} \mathrm{C}$ and the pellet was washed by suspension and re-centrifugation in cold $70 \%(\mathrm{v} / \mathrm{v})$ ethanol and finally dried under vacuum. The pellet was dissolved in $3.5 \mu \mathrm{l}$ water and $3.5 \mu \mathrm{l} 5 \mathrm{M}$ lithium chloride were added. The whole was left either on ice for at least $1 \mathrm{~h}$ or overnight at $-20^{\circ} \mathrm{C}$ to precipitate RNA. The purified nucleic acid was collected by centrifugation at $4{ }^{\circ} \mathrm{C}$, washed by suspension and centrifugation in cold $70 \%$ ethanol and dried under vacuum. The pellet was dissolved in $3 \mu \mathrm{l}$ water and $15 \mu \mathrm{l}$ deionized formamide buffer $(500 \mu \mathrm{l}$ deionized formamide, $100 \mu \mathrm{l}$ $1 \times$ MOPS buffer, $150 \mu \mathrm{l} 38 \%$ formaldehyde; this buffer was stored at $\left.-20^{\circ} \mathrm{C}\right)$. MOPS buffer $(1 \times)$ was made from a $5 \times$ stock of $0 \cdot 1 \mathrm{M}$ MOPS (pH 7.0), $40 \mathrm{mM}$ sodium acetate and $5 \mathrm{mM}$ EDTA ( $\mathrm{pH} \mathrm{8.0)}$. Deionized formamide was made by stirring $1 \mathrm{~g} \mathrm{AG} 501-\mathrm{X} 8$ mixed bed resin (Bio-Rad) with $20 \mathrm{ml}$ formamide. Deionized formamide was stored at $-20^{\circ} \mathrm{C}$ in airtight cryovials. 
(a)

Unk Jle Gln (Thr) Thr Pro Val Thr Gln Trp Gly Leu Ser Arg Ile Ser His (Lys Lys) Ala Gln Thr Gly Asn Tyr Ala Tyr Val Arg Glu Thr Val Gly Lys His Pro Thr Val Ser Tyr Val Val Asp Ser Gly Ile Arg (Thr) Thr His Ser Glu

(b)

Ala Ser Ser Gly Pro Ile Thr Ala Glu Leu Tyr Asn Glu Leu Met Ala Tyr Gln Val Gln Ile Ser Leu Gly Gly Gln Thr Ile Ser Ala Ser Ile Asp Thr Gly Ser Glu Ile Leu Trp Val Trp Glu Asn Asp Ser Ile Ala Cys Gln Val Asp Gln Gin Asp

Fig. 1. N-terminal sequences of $Y$. lipolytica 148 extracellular proteases. (a) AEP. Unk could not be assigned; residues in parentheses were not unequivocally identified but represent the most probable interpretation of sequencing data (see text). (b) AXP. Codons for the residues in bold were used to specify the mixed oligonucleotide probe employed to identify the cloned gene.

The nucleic acid was denatured by incubation at $60{ }^{\circ} \mathrm{C}$ for $15 \mathrm{~min}$, cooled on ice and mixed with $3 \mu \mathrm{l} 6 \times \mathrm{RNA}$ loading buffer: $5 \%(\mathrm{v} / \mathrm{v})$ glycerol, $1 \mathrm{mM}$ EDTA ( $\mathrm{pH} 8.0$ ), $0.25 \%$ bromophenol blue, $0 \cdot 25 \%$ xylene cyanol FF. Samples were electrophoresed in $1.5 \%$ agarose-formaldehyde gels (Sambrook et al., 1989). Tanks with large buffer reservoirs (Pharmacia GNA 200 ) were used and electrophoresis was at $3-4 \mathrm{~V} \mathrm{~cm}^{-1}$. Half way through the run, electophoresis was stopped and the electrophoresis buffer $(1 \times$ MOPS) was removed from the anode and cathode reservoirs, mixed, returned and the electrophoresis was re-started. The lane containing markers was cut from the gel and stained in $0 \cdot 2 \mu \mathrm{g}$ ethidium bromide $\mathrm{ml}^{-1}$ for $25 \mathrm{~min}$. The gel was washed by three consecutive $10 \mathrm{~min}$ washes with water to remove formaldehyde, and photographed using transmitted UV illumination. The remainder of the gel was neutralized by soaking in $10 \%(\mathrm{w} / \mathrm{v})$ glycine for $25 \mathrm{~min}$ and processed for Northern blotting.

Northern blotting. The methods described by Sambrook et al. (1989) were used. Probes were made by PCR $\left(30\right.$ cycles of $94^{\circ} \mathrm{C}$ for $30 \mathrm{~s}, 50^{\circ} \mathrm{C}$ for $30 \mathrm{~s}$ and $72{ }^{\circ} \mathrm{C}$ for $60 \mathrm{~s}$ ) using $5^{\prime}$ and $3^{\prime}$ primers to the published gene sequences of $Y$. lipolytica AEP (Davidow et al., 1987a). The primers were made to bases 2356-2379 (5') and 2590-2613 (3'). A probe for the Yarrowia AXP (this paper) was made from a $255 \mathrm{bp} \mathrm{BamHI-Ncol} \mathrm{fragment} \mathrm{obtained} \mathrm{from} \mathrm{a}$ 500 bp BamHI-Sall fragment of clone 13.1 subcloned in pUC9.
The probe extends from the $5^{\prime} \mathrm{BamHI}$ site to the first NcoI site. Probes were purified by gel electrophoresis and electroelution.

\section{RESULTS AND DISCUSSION}

\section{Classification of C. olea 148}

The identity score (maximum value 1.0000000 ) was 0.9999722 with $Y$. lipolytica. No other yeast in the database gave scores close to this value. Taken together with the sequence data for the alkaline protease and the codon usage (see below), it is clear that $C$. olea 148 is indeed a strain of $Y$. lipolytica.

\section{Purification of extracellular proteases and $\mathbf{N}$-terminal sequences}

A single acid protease with an estimated $M_{\mathrm{r}}$ by SDSPAGE of 39000 was purified to greater than $98 \%$ purity as judged by SDS-PAGE. The enzyme eluted from Mono $Q$ in a single peak of activity $19 \mathrm{ml}$ into the salt gradient, and $30 \mu \mathrm{g}$ was used for obtaining the $\mathrm{N}$-terminal sequence. The alkaline protease eluted from the Mono Q column after $15 \mathrm{ml}$ of salt gradient and was greater than $95 \%$ pure as judged by SDS-PAGE, and $120 \mu \mathrm{g}$ was used for $\mathrm{N}$ terminal sequencing. The $\mathrm{N}$-terminal sequences of both enzymes are shown in Fig. 1.

For the alkaline protease, the $\mathrm{N}$-terminal amino acid and residues at positions 4,18, 19 and 48 were not unequivocally characterized. However, data (not shown) indicated that the most probable residue at both 4 and 48 is Thr. With these assignments, 49 of the 52 residues are identical to those reported by Davidow et al. (1987a) for the AEP from $Y$. lipolytica. In the latter enzyme, positions 18 and 19 are occupied by Lys. Given the fact that difficulties are frequently experienced in sequencing Lys, it is reasonable to assume that both 18 and 19 are Lys residues in the $Y$. lipolytica 148 sequence, and it seems likely that this organism secretes the same AEP as other strains of $Y$. lipolytica.

The sequence obtained from the acid protease was unique when compared to proteins in the SWISS-PROT database

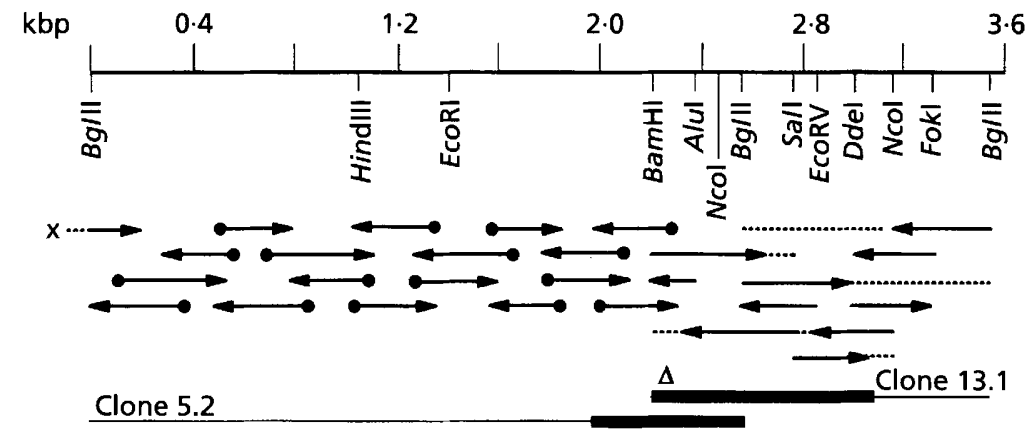

Fig. 2. Sequencing strategy for $Y$. lipolytica 148 genomic DNA. The genomic DNA was contained in two overlapping clones $(5.2$ and 13.1) as shown. For clone 13.1 (see text), the filled box denotes the ORF surrounding the oligonucleotide probe site $(\Delta)$. The direction and extent of sequencing of restriction fragments are shown by continuous arrows. Broken lines show unsequenced regions. For clone 5.2 (see text), the filled box denotes the position of the ORF encoding the acid protease. Oligonucleotide 17-mer primers are shown by and the arrows show the direction and extent of sequencing; $x$ denotes a primer made to vector sequence. The region from BamHI (at about $2 \cdot 2 \mathrm{kbp}$ ) to the $3^{\prime}$ end overlaps the 5 region of clone 13.1 . 


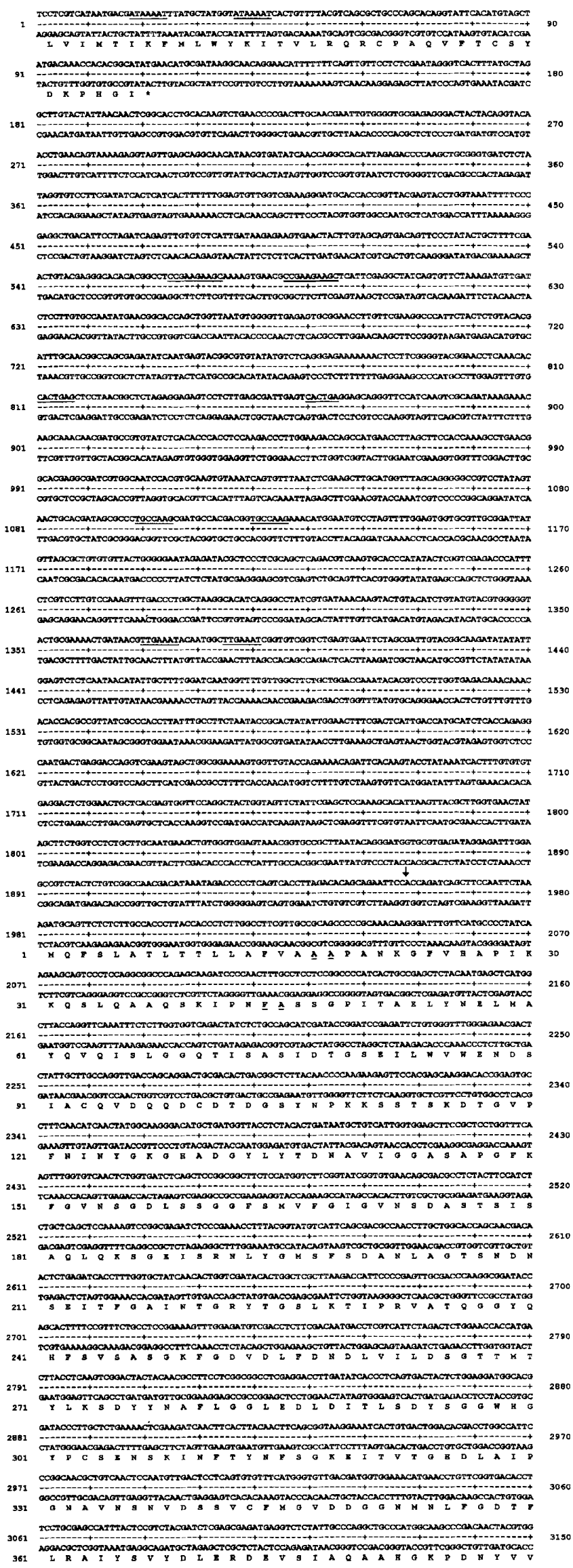

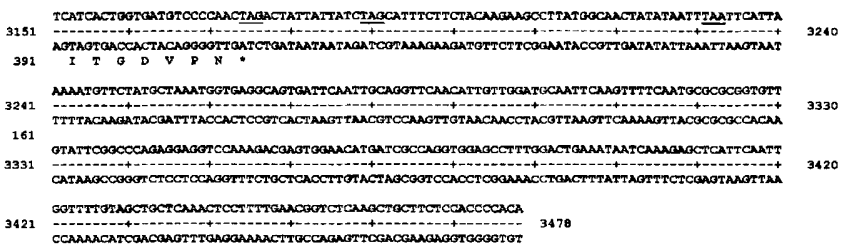

Fig. 3. Complete sequence of $Y$. lipolytica cloned DNA containing the gene for the AXP. Regions of repeated sequence are underlined. The probable transcription start site is shown by the arrow. The coding region for the AXP gene begins at 1983 and ends at 3176; the first, second and third stop codons are shown in bold and underlined. The extreme $5^{\prime}$ translation is a putative open reading frame. No other ORFs of significant size were detected. The translated sequence is shown as singleletter code. Underlined amino acids: $\mathrm{Ala}_{17}$ and $\mathrm{Ala}_{18}$, predicted site of signal cleavage; $\mathrm{Phe}_{44}$ and $\mathrm{Ala}_{45}$, mature sequence cleavage site.

using the UWGCG TFASTA program. It did however show $44.4 \%$ identity in a 36 amino acid overlap with an aspartyl protease, endothiapepsin, from the chestnut blight fungus, Cryphonectria parasitica (Endotbia parasitica) (Razanamparany et al., 1992).

\section{Gene cloning}

A mixed 18-mer oligonucleotide was synthesized corresponding to amino acids $\operatorname{Trp}_{40}$ to $\mathrm{Asp}_{45}$ of the purified acid protease (Fig. 1). The mixture comprised 16 oligonucleotides (only the forms with $\mathrm{T}$ at the $3^{\prime}$ end were made). This was labelled and used to probe the BamHI library made in E. coli DH5, and from the first screen, 15 presumptive positive clones were isolated. These were rescreened and four positives were obtained. These four were sequenced and only one (designated 13.1) contained sequence identical to both the probe and the N-terminal sequence of the secreted AXP. The $5^{\prime}$ end of the cloned DNA corresponded to residue $\mathrm{Gly}_{35}$ of the N-terminal protein sequence.

To obtain the regions $5^{\prime}$ to clone 13.1 , restriction digests of Yarrowia genomic DNA were probed with a 329 bp $B a m \mathrm{HI}-\mathrm{Bg} / \mathrm{II}$ fragment from the $5^{\prime}$ end of the clone (see Fig. 2). This screen identified an approximately $2.5 \mathrm{~kb}$ $B g / \mathrm{II}$ fragment which would contain the $\mathrm{N}$-terminus of the enzyme and upstream sequences. This fragment was isolated from a $B g / I I$ library by colony hybridization using the 329 bp $B a m H I-B g / I I$ fragment of clone 13.1 as a probe. The isolated clone was designated 5.2.

\section{Gene sequencing}

The sequencing strategies for clones 13.1 and 5.2 are shown in Fig. 2. The $3^{\prime}$ end of 5.2 overlaps the $5^{\prime}$ end of 13.1. Both strands were sequenced in both directions and all segments overlap. The complete sequence of $3478 \mathrm{bp}$ of Yarrowia DNA including the coding sequence and its translation are presented in Fig. 3. Computer analysis 
Table 1. Comparison of the percentage frequency of codon usage for the AXP gene of $Y$. lipolytica with the combined usage of the genes for the AEP (XPR2), $\beta$-isopropylmalate dehydrogenase (LEU2) and pyruvate kinase (PYK1)

\begin{tabular}{|c|c|c|c|c|c|c|c|}
\hline Codon & $\begin{array}{l}\text { Amino } \\
\text { acid }\end{array}$ & $\begin{array}{c}\text { Frequency } \\
A X P\end{array}$ & $\begin{array}{c}\text { Frequency } \\
\text { XPR2, } \\
\text { LEU2, } \\
\text { PYK1 }\end{array}$ & Codon & $\begin{array}{l}\text { Amino } \\
\text { acid }\end{array}$ & $\begin{array}{c}\text { Frequency } \\
A X P\end{array}$ & $\begin{array}{c}\text { Frequency } \\
\text { XPR2, } \\
\text { LEU2, } \\
\text { PYK1 }\end{array}$ \\
\hline GGG & Gly & $0 \cdot 0$ & $0 \cdot 1$ & TGG & $\operatorname{Trp}$ & 0.8 & $0 \cdot 9$ \\
\hline GGA & Gly & $3 \cdot 5$ & $2 \cdot 5$ & TGA & End & $0 \cdot 0$ & $0 \cdot 0$ \\
\hline GGT & Gly & $4 \cdot 3$ & $3 \cdot 0$ & TGT & Cys & $0 \cdot 3$ & $0 \cdot 8$ \\
\hline GGC & Gly & $3 \cdot 3$ & $3 \cdot 2$ & TGC & Cys & $0 \cdot 8$ & $0 \cdot 3$ \\
\hline GAG & Glu & $2 \cdot 3$ & $4 \cdot 7$ & TAG & End & $0 \cdot 0$ & $0 \cdot 1$ \\
\hline GAA & Glu & 0.5 & $0 \cdot 3$ & TAA & End & $0 \cdot 0$ & $0 \cdot 1$ \\
\hline GAT & Asp & $2 \cdot 5$ & $2 \cdot 1$ & TAT & Tyr & $0 \cdot 3$ & $0 \cdot 2$ \\
\hline GAC & Asp & $5 \cdot 3$ & $4 \cdot 2$ & TAC & Tyr & $4 \cdot 3$ & $2 \cdot 2$ \\
\hline GTG & Val & $1 \cdot 3$ & $1 \cdot 6$ & TTG & Leu & $0 \cdot 3$ & $0 \cdot 4$ \\
\hline GTA & Val & $0 \cdot 0$ & $0 \cdot 1$ & TTA & Leu & $0 \cdot 0$ & $0 \cdot 1$ \\
\hline GTT & Val & $2 \cdot 3$ & $2 \cdot 7$ & TTT & Phe & $1 \cdot 5$ & $1 \cdot 2$ \\
\hline GTC & Val & $2 \cdot 5$ & $3 \cdot 7$ & T'TC & Phe & $3 \cdot 5$ & $2 \cdot 1$ \\
\hline GCG & Ala & 0.5 & $0 \cdot 1$ & TCG & Ser & $0 \cdot 8$ & $0 \cdot 8$ \\
\hline GCA & $\mathrm{Ala}$ & 0.5 & $0 \cdot 4$ & TCA & Ser & 0.5 & $0 \cdot 2$ \\
\hline GCT & $\mathrm{Ala}$ & $2 \cdot 8$ & $3 \cdot 3$ & TCT & Ser & $3 \cdot 5$ & $3 \cdot 0$ \\
\hline GCC & $\mathrm{Ala}$ & $4 \cdot 3$ & $5 \cdot 8$ & TCC & Ser & $4 \cdot 0$ & $4 \cdot 1$ \\
\hline AGG & Arg & $0 \cdot 0$ & $0 \cdot 3$ & CGG & Arg & $0 \cdot 0$ & $0 \cdot 1$ \\
\hline AGA & Arg & $0 \cdot 0$ & $0 \cdot 1$ & CGA & Arg & $1 \cdot 3$ & $3 \cdot 3$ \\
\hline$A G T$ & Ser & 0.5 & $0 \cdot 4$ & CGT & Arg & $0 \cdot 0$ & $0 \cdot 0$ \\
\hline $\mathrm{AGC}$ & Ser & $2 \cdot 0$ & 0.4 & CGC & Arg & $0 \cdot 0$ & $0 \cdot 1$ \\
\hline AAG & Lys & $4 \cdot 0$ & $5 \cdot 8$ & $\mathrm{CAG}$ & Gln & $3 \cdot 0$ & $2 \cdot 7$ \\
\hline $\mathrm{AAA}$ & Lys & $0 \cdot 0$ & $0 \cdot 2$ & CAA & Gln & 0.8 & $0 \cdot 1$ \\
\hline $\mathrm{AAT}$ & Asn & $1 \cdot 0$ & $0 \cdot 4$ & CAT & His & $0 \cdot 8$ & $0 \cdot 2$ \\
\hline $\mathrm{AAC}$ & Asn & $5 \cdot 8$ & $3 \cdot 8$ & CAC & His & 0.8 & $1 \cdot 2$ \\
\hline ATG & Met & $1 \cdot 8$ & 1.9 & CTG & Leu & $1 \cdot 0$ & $3 \cdot 2$ \\
\hline ATA & Ile & $0 \cdot 0$ & $0 \cdot 0$ & CTA & Leu & $0 \cdot 3$ & $0 \cdot 4$ \\
\hline $\mathrm{ATT}$ & Ile & $2 \cdot 3$ & $3 \cdot 0$ & CTT & Leu & $1 \cdot 8$ & $1 \cdot 4$ \\
\hline ATC & Ile & $3 \cdot 8$ & $3 \cdot 6$ & СТC & Leu & $3 \cdot 5$ & $2 \cdot 9$ \\
\hline ACG & Thr & $0 \cdot 3$ & 0.4 & $\mathrm{CCG}$ & Pro & $0 \cdot 0$ & $0 \cdot 1$ \\
\hline $\mathrm{ACA}$ & Thr & $0 \cdot 0$ & 0.7 & CCA & Pro & $0 \cdot 0$ & $0 \cdot 1$ \\
\hline $\mathrm{ACT}$ & Thr & $3 \cdot 0$ & $1 \cdot 8$ & СCT & Pro & $1 \cdot 0$ & $1 \cdot 2$ \\
\hline $\mathrm{ACC}$ & Thr & $3 \cdot 3$ & $4 \cdot 0$ & $\mathrm{CCC}$ & Pro & $2 \cdot 0$ & $3 \cdot 2$ \\
\hline
\end{tabular}

shows a large open reading frame extending from 1983 to 3173. Within this open reading frame lies the $\mathrm{N}$-terminus of the mature secreted AXP beginning with Ala at $2115 \mathrm{bp}$. The first stop codon is at $3174 \mathrm{bp}$. The mature enzyme is therefore 353 amino acids in length.

\section{Codon usage}

Values calculated for codon usage in the AXP are presented in Table 1 together with combined values for three highly expressed $Y$. lipolytica genes, XPR2 (Davidow et al., 1987a), LEU2 (Davidow et al., 1987b) and PYK1 (Strick et al., 1992). There is very good agreement in terms of preferred codon usage throughout. CGT (4rg) and ATA (Ile) remain unused and TGA was not found as the first stop codon.

\section{Comparison with other proteins}

Comparison of the sequence of mature AXP with proteins in the database using the program FASTA gave a best score with the candidapepsin 1 precursor of C. albicans. Table 2 shows the results of the analysis for the 22 best scores. With the exception of progastricin precursors from human and Macaque monkey and a cathepsin E precursor from rabbit, all other matches are to fungal enzymes. The majority are from the yeast genus Candida; $C$. albicans secreted aspartyl proteases (candidapepsins precursors 1-7) and enzymes from Candida parapsilosis and $C$. tropicalis. The precursor of the acid protease from the yeast Saccharomycopsis fibuligera (taxonomically the most closely related yeast) is eleventh in the list. Related enzyme precursors are also found in the fungal genera 
Table 2. Proteins in the SWISS-PROT database showing similarity to the secreted AXP of Y. lipolytica 148

\begin{tabular}{|c|c|c|c|c|c|}
\hline SWISS-PROT & $\begin{array}{l}\text { Accession } \\
\text { no. }\end{array}$ & Description & Organism & $\begin{array}{l}\text { Identity } \\
\quad(\%)\end{array}$ & $\begin{array}{l}\text { Overlap } \\
\text { (aa) }\end{array}$ \\
\hline sw:car1_canal & P28872 & $\begin{array}{l}\text { Candidapepsin } 1 \text { precursor (EC 3.4.23.24) } \\
\text { (ACP) }\end{array}$ & Candida albicans & $26 \cdot 6$ & 353 \\
\hline sw:car2_canal & P28871 & $\begin{array}{l}\text { Candidapepsin } 2 \text { precursor (EC } 3.4 .23 .24 \text { ) } \\
(\mathrm{ACP})\end{array}$ & Candida albicans & $26 \cdot 2$ & 370 \\
\hline sw:yap3_yeast & P32329 & $\begin{array}{l}\text { Aspartic proteinase } 3 \text { precursor } \\
\text { (EC } 3.4 .23 .{ }_{-} \text {) }\end{array}$ & Saccharomyces cerevisiae & $22 \cdot 8$ & 395 \\
\hline sw:car4_canal & P43093 & Candidapepsin 4 precursor (EC 3.4.23.24) & Candida albicans & $28 \cdot 6$ & 357 \\
\hline sw:car7_canal & P43096 & Candidapepsin 7 precursor (EC 3.4.23.24) & Candida albicans & $23 \cdot 7$ & 211 \\
\hline sw:pepc_human & P20142 & $\begin{array}{l}\text { Progastricsin precursor (EC 3.4.23.3) } \\
\text { (pepsinogen C) }\end{array}$ & Homo sapiens & $22 \cdot 4$ & 330 \\
\hline sw : pepc_macfu & P03955 & $\begin{array}{l}\text { Progastricsin precursor (EC 3.4.23.3) } \\
\text { (pepsinogen C) (fragment) }\end{array}$ & Macata fuscata & $22 \cdot 7$ & 330 \\
\hline sw : car3_rhini & Q03699 & Rhizopuspepsin 3 precursor (EC 3.4.23.21) & Rbizopus niveus & $25 \cdot 2$ & 337 \\
\hline sw : car5_canal & P43094 & Candidapepsin 5 precursor (EC 3.4 .23 .24 ) & Candida albicans & $26 \cdot 8$ & 355 \\
\hline sw : car1_rhini & P10602 & Rhizopuspepsin precursor (EC 3.4.23.21) & Rhizopus niveus & $24 \cdot 0$ & 371 \\
\hline sw: carp_sacfi & P22929 & Acid protease precursor (EC 3.4.23._) & Saccharomycopsis fibuligera & $26 \cdot 7$ & 345 \\
\hline sw:car6_canal & P43095 & Candidapepsin 6 precursor (EC 3.4 .23 .24 ) & Candida albicans & $27 \cdot 8$ & 353 \\
\hline sw:car3_canal & P43092 & Candidapepsin 3 precursor (EC 3.4 .23 .24 ) & Candida albicans & $26 \cdot 5$ & 351 \\
\hline sw:carv_canal & P10977 & $\begin{array}{l}\text { Candidapepsin } 1 \text { precursor (EC } 3.4 .23 .24 \text { ) } \\
\text { (ACP) }\end{array}$ & Candida albicans & $24 \cdot 3$ & 342 \\
\hline sw: carp_rhich & P06026 & $\begin{array}{l}\text { Rhizopuspepsin precursor (EC 3.4.23.21) } \\
\text { (fragment) }\end{array}$ & Rbizopus cbinensis & $23 \cdot 5$ & 362 \\
\hline sw: car1_canpa & P32951 & Candidapepsin 1 precursor (EC 3.4.23.24) & Candida parapsilosis & $25 \cdot 0$ & 360 \\
\hline sw : carp_cantr & Q00663 & $\begin{array}{l}\text { Candidapepsin precursor (EC 3.4.23.24) } \\
(\mathrm{ACP})\end{array}$ & Candida tropicalis & $23 \cdot 9$ & 368 \\
\hline sw : carp_rhipu & P09177 & $\begin{array}{l}\text { Mucoropepsin precursor (EC 3.4.23.23) } \\
\text { (Mucor rennin) }\end{array}$ & Rbizomucor pusillus & $21 \cdot 6$ & 338 \\
\hline sw: cate_rabit & P43159 & Cathepsin E precursor (EC 3.4.23.34) & Oryctolagus cuniculus & $24 \cdot 1$ & 336 \\
\hline sw:sxa1_schpo & P328341 & $\begin{array}{l}\text { 1 Aspartic protease Sxa1 precursor (EC } \\
3.4 .23 .{ }_{-} \text {) }\end{array}$ & Schizosaccharomyces pombe & $17 \cdot 7$ & 317 \\
\hline sw : carp_rhimi & P00799 & $\begin{array}{l}\text { Mucoropepsin precursor (EC 3.4.23.23) } \\
\text { (Mucor rennin) }\end{array}$ & Rhizomucor meibei & $24 \cdot 2$ & 219 \\
\hline sw : carp_crypa & P11838 & Endothiapepsin precursor (EC 3.4.23.22) & Cryphonectria parasitica & $28 \cdot 4$ & 317 \\
\hline
\end{tabular}

Rhizopus and Cryphonectria. Fig. 4 shows a comparison, using the program CLUSTAL v (Higgins et al., 1991) of the amino acid sequence of prepro AXP with the sequences of six of the proteins of 'Table 2 . In common with these other proteases, AXP contains two active site Asp(Ser/Thr)Gly motifs characteristic of aspartyl proteases. The active site Asp residues are marked by arrows in Fig. 4. No homology is detected between the prepro region of AXP and the other proteins.

Although AXP apparently differs in $M_{\mathrm{r}}$, inhibition by diazoacetyl-norleucine methyl ester and 1,2-epoxy-3( $p$ nitrophenoxy)-propane (Nelson \& Young, 1986) from the enzymes from $Y$. lipolytica CX161-1B (Yamada \& Ogrydziak, 1983), sequence from clone 13.1 has been used to successfully disrupt (by integrative transformation) acid protease production in $Y$. lipolytica (C. Gaillardin, personal communication). It seems highly likely therefore that the enzyme is produced by other Yarrowia strains. It is not clear at present, however, which if any of the three AXPs reported for strain CX161-1B correspond to AXP from strain 148 .

\section{The preproenzyme, glycosylation and processing}

The preproenzyme comprises 397 residues and has an $M_{\mathrm{r}}$ of 42081 . The first 18 residues of the amino terminus are all significantly hydrophobic. Using the weight matrix for eukaryotic signal peptide cleavage sites of von Heijne (1986), the predicted site is between $\mathrm{Ala}_{17}$ and $\mathrm{Ala}_{18}$. This site shows a $P$ value of 11.4 . Alternative but much less likely sites are given at $\mathrm{Ala}_{13} / \mathrm{Phe}_{14}, \mathrm{Ala}_{18} / \mathrm{Pro}_{19}$ and $\mathrm{Ala}_{20} / \mathrm{Asn}_{21}$, with $P$ values of $1 \cdot 8,0.6$ and $2 \cdot 3$, respectively. There are no $N$-glycosylation sites in the pro region of the protein and the mature enzyme is produced by cleavage between $\mathrm{Phe}_{\mathbf{4 4}}$ and $\mathrm{Ala}_{45}$, and comprises 353 amino acids and has a calculated $M_{\mathrm{r}}$ of 37427 and pI of 4.05 which agrees well with the biochemical estimates (39000 and $4 \cdot 1$, respectively). Comparison of the pro region of AXP with those of other secreted yeast proteases (acid proteases from C. albicans strains 10231 and 10261, C. tropicalis, Saccharomycopsis fibuligera and the AEP of $Y$. lipolytica) reveals striking differences. It is much shorter, it contains no $N$-linked glycosylation sequences and lacks a Lys-Arg cleavage site immediately preceding the $\mathrm{N}$-terminus of the 


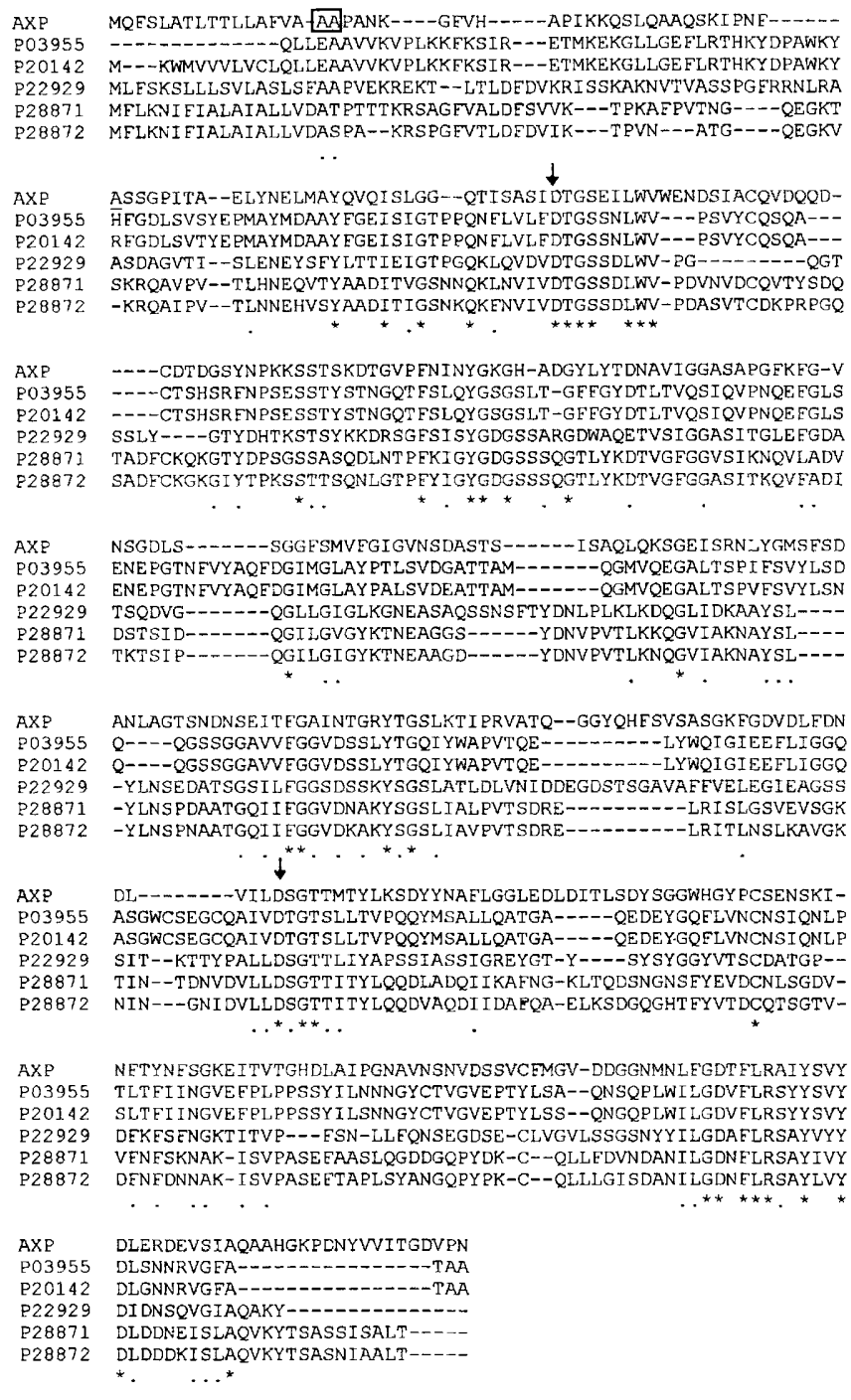

Fig. 4. Alignment of amino acid sequence of AXP with asparty proteases using the computer program CLUSTAL V. Descriptions are given alongside the accession numbers in Table 2 . The predicted signal cleavage site of AXP is boxed and the $\mathrm{N}$ terminal amino acid of the mature protein is underlined ( $A$, line 7). Conserved residues are denoted by an asterisk and 'conservative replacements' by a full stop. The conserved active site aspartate residues of the aspartyl group of proteolytic enzymes are indicated by arrows.

secreted protein. It appears therefore that the secretory motif of $Y$. lipolytica acid protease is distinct from the common motif for yeast extracellular protease processing suggested by Ogrydziak (1993). Of particular note is the lack of the Lys-Arg (or Arg-Arg) processing site in the propeptide.

\section{Sequence upstream and downstream of the AXP gene}

Computer analysis indicates ORFs in each of the three reading frames from the $5^{\prime}$ end (the largest is from 3 to 111, Fig. 3). None of the translated sequences show

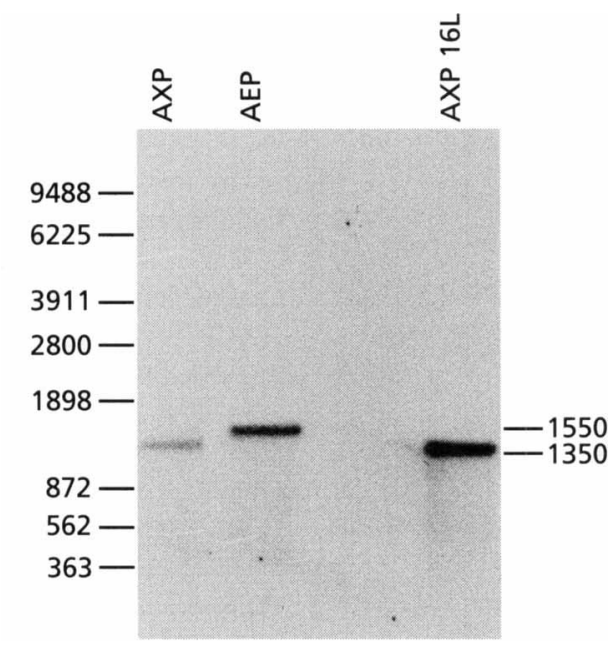

Fig. 5. Northern blots of total RNA extracts of $Y$. lipolytica cultured at different values of $\mathrm{pH}$. A mixture of probes specific for AXP and AEP transcripts was used simultaneously. Lane AXP buffered culture at $\mathrm{pH} 5.5$ and AEP buffered culture at $\mathrm{pH} 7.5$. Lane AXP $16 \mathrm{~L}$ from a batch culture unbuffered but with automatic $\mathrm{pH}$ control set at $\mathrm{pH} 4.5$.

convincing homology to other sequences. Accordingly, the AXP gene potentially contains a $1982 \mathrm{bp}$ upstream regulatory region. Analysis of mRNA by $5^{\prime}$ extension (data not shown) indicates that the transcription start is at position 1957.

No sequence matching the consensus for $\mathrm{pH}$ regulation reported for A. niger (Jarai \& Buxton, 1994) is present. However, in the AXP sequence, two hexanucleotide sequences corresponding to the core recognition sequence of the ipn A promoter (Tilburn et al., 1995) are found. The core sequence $5^{\prime}$ GCCARG $3^{\prime}$ is found at positions 1100 and 1121 on the top strand

Downstream of the coding region, second and third stop codons are found at positions 3189 and 3231, respectively (Fig. 3). No consensus polyadenylation site has been detected. The estimated size of the transcript is thus at least 1217 bases.

\section{Effect of environmental pH on transcription of AEP and AXP}

Total RNA, isolated from strain 148 grown at $\mathrm{pH} 5.5$ and 7.5 in buffered batch culture, was separated by electrophoresis under denaturing conditions and probed with labelled probes specific to AEP and AXP sequences. Transcript sizes were estimated as 1350 bases for AXP and 1550 for AEP (Fig. 5). The results presented in Fig. 5 also show that under acid conditions only AXP transcript is detected and under alkaline conditions only AEP. That the observations with regard to AXP transcript result from $\mathrm{pH}$ and not the influence of buffering ions was shown by growing the cells in culture at $\mathrm{pH} 4.5$ with $\mathrm{pH}$ control (by automated acid or base addition in response to culture $\mathrm{pH}$ ). Here also, only AXP transcript was detected (Fig. 5). The most likely explanation of the observations 
is that environmental $\mathrm{pH}$ regulates the transcription apparatus. Precisely how this is achieved remains to be determined; it may, as in Aspergillus, involve a PacC-type gene product. However if it does, the regulatory events in Yarrowia must be more complex since the AEP promoter does not contain a pacC core recognition sequence. Alternatively an as-yet-unidentified transcription factor or factors with different specificities may be involved.

\section{REFERENCES}

Beggs, J. D. (1978). Transformation of yeast by a replicating hybrid plasmid. Nature 275, 104-109.

Berger, S. L. (1987a). Preparation and characterization of RNA: overview. Methods Enzymol 152, 215-219.

Berger, S. L. (1987b). Isolation of cytoplasmic RNA: ribonucleoside vanadyl complexes. Methods Enzymol 152, 227-234.

Blanchin-Roland, S., Otero, R. R. C. \& Gaillardin, C. (1994). Two upstream activation sequences control the expression of the XPR2 gene in the yeast Yarrowia lipolytica. Mol Cell Biol 14, 327-338.

Davidow, L. S., O'Donnell, M. M., Kaczmarek, F. S., Pereira, D. A., De Zeeuw, J. R. \& Franke, A. E. (1987a). Cloning and sequencing of the alkaline extracellular protease gene of Yarrowia lipolytica. $J$ Bacteriol 169, 4621-4629.

Davidow, L. S., Kaczmarek, F. S., De Zeeuw, J. R., Conlon, S. W., Lauth, M. R., Pereira, D. A. \& Franke, A. E. (1987b). The Yarrowia lipolytica LEU2 gene. Curr Genet 11, 377-383.

Hanahan, D. (1985). Techniques for transformation of E. coli. In DN A Cloning: a Practical Approach, vol. 1, pp. 109-135. Edited by D. M. Glover. Oxford: IRL Press.

von Heijne, H. (1986). A new method for predicting signal sequence cleavage sites. Nucleic Acids Res 14, 4683-4690.

Heslot, H. (1990). Genetics and genetic engineering of the industrial yeast Yarrowia lipolytica. Adv Biachem Eng Biotechnol 43, 43-73.

Higgins, D. G., Bleasby, A. J. \& Fuchs, R. (1991). Clustal v: improved software for multiple sequence alignment. CABIOS $\mathbf{8}$, 189-191.

Hirata, D., Fukui, S. \& Yamashita, I. (1988). Nucleotide sequence of the secretable acid protease gene PEP1 in the yeast Saccharomycopsis fibuligera. Agric Biol Chem 52, 2647-2649.

Hube, B., Turver, C. J., Odds, F. C., Eiffert, H., Boulnois, G. J., Kochel, H. \& Ruchel, R. (1991). Sequence of the Candida albicans gene encoding the secretory aspartate protease. J Med Vet Mycol 29, 129-132.

Hube, B., Monod, M., Scholfield, D. A., Brown, A. J. P. \& Gow, N. A. R. (1994). Expression of seven members of the gene family encoding secretory aspartyl proteases in Candida albicans. Mol Microbiol 14, 87-99.

Jarai, G. \& Buxton, F. (1994). Nitrogen, carbon and $\mathrm{pH}$ regulation of extracellular acidic proteases of Aspergillus niger. Curr Genet 26, 238-244.

Johnson, M. \& Davis, R. W. (1984). Sequences that regulate the divergent Gal1-Gal 10 promoter in Saccharomyces cerevisiae. Mol Cell Biol 4, 1440-1448.
Kohrer, K. \& Domdey, H. (1991). Preparation of high molecular weight RNA. Methods Enzymol 194, 398-405.

Kreger-van Rij, N. J. W. (1984). Genus 24. Saccharomycopsis Schiönning. In The Yeasts: a Taxonomic Study, 4th edn, pp. 319-413. Edited by N. J. W. Kreger-van Rij. Amsterdam: Elsevier.

Matoba, S., Fukayama, J., Wing, R. A. \& Ogrydziak, D. M. (1988). Intracellular precursors and secretion of alkaline extracellular protease of Yarrowia lipolytica. Mol Cell Biol 8, 4904-4916.

Messing, J. (1983). New M13 vectors for cloning. Methods Enzymol 101, 20-78.

Nelson, G. (1986). Yeast extracellular proteases and their applications in the brewing industry. $\mathrm{PhD}$ thesis, University of Birmingham.

Nelson, G. \& Young, T. W. (1986). Yeast extracellular proteases for chill-proofing beer. J Inst Brew 92, 599-603.

Nelson, G. \& Young, T. W. (1987). Extracellular acid and alkaline proteases from Candida olea. J Gen Microbiol 133, 1461-1469.

Ogrydziak, D. M. (1993). Yeast extracellular proteases. Crit Rev Biotechnol 13, 1-55.

Ogrydziak, D. M. \& Scharf, S. J. (1982). Alkaline extracellular protease produced by Saccharomycopsis lipolytica CX161-1B. J Gen Microbiol 128, 1225-1234.

Orejas, M., Espeso, E. A., Tilburn, J., Sarkar, S., Arst, H. N., Jr \& Penalva, M. A. (1995). Activation of the Aspergillus PacC transcription factor in response to alkaline ambient $\mathrm{pH}$ requires proteolysis of the carboxy-terminal moiety. Genes Dev 9, 1622-1632.

Quincey, R. V. \& Arnold, R. E. (1984). Transcription of a yeast ribosomal RNA minigene in Saccharomyces cerevisiae. Biocbem J 224, 497-503.

Razanamparany, V., Jara, P., Legoux, R., Delmas, P., Msayeh, F., Kaghad, M. \& Loison, G. (1992). Cloning and mutation of the gene encoding endothiapepsin from Cryphonectria parasitica. Curr Genet 21, 455-461.

Riggsby, W. S., Torres-bauza, L. J., Wills, J. W. \& Townes, T. M. (1982). DNA content, kinetic complexity and the ploidy question in Candida albicans. Mol Cell Biol 2, 853-862.

Sambrook, J., Fritsch, E. F. \& Maniatis, T. (1989). Molecular Cloning: a Laboratory Manual, 2nd edn. Cold Spring Harbor, NY: Cold Spring Harbor Laboratory.

Strick, C. A., James, L. C., O’Donnell, M. M., Gollaher, M. G. \& Franke, A. E. (1992). The isolation and characterization of the pyruvate kinase-encoding gene from the yeast Yarrowia lipolytica. Gene 118, 65-72.

Tilburn, J., Sarkar, S., Widdick, D. A., Espeso, E. A., Orejas, M., Mungroo, J., Peñalva, M. A. \& Arst, H. N., Jr (1995). The Aspergillus $\mathrm{PacC}$ zinc finger transcription factor mediates regulation of both acid- and alkaline-expressed genes by environmental $\mathrm{pH}$. EMBO J 14, 779-790.

Togni, G., Sanglard, D., Falchetto, R. \& Monod, M. (1991). Isolation and nucleotide sequence of the extracellular acid protease gene (ACP) from the yeast Candida tropicalis. FEBS Lett 286, 181-185.

Yamada, T. \& Ogrydziak, D. M. (1983). Extracellular acid proteases produced by Saccharomycopsis lipolytica. J Bacteriol 154, 23-31.

Received 9 April 1996; revised 28 May 1996; accepted 31 May 1996. 